\title{
From Outposts to Enclaves: A Social History of Black Barbers from 1750 to 1915
}

DOUGLAS BRISTOL, JR.

The story of black barbers contributes to the recent effort of business historians to engage the larger culture by bringing together business and African American history. While exploring issues commonly associated with the history of the firm uncovered a tradition of enterprise that stretches back to the early nineteenth century, investigating questions from the repertoire of social history sheds new light on race relations and ideological debates within the African American community. The men whose lives are chronicled by this dissertation also emerge as figures worthy of historical study on their own merit; in addition to becoming the most successful African American businessmen in the nineteenth century, black barbers distinguished themselves through their wit, savoir-faire, and tenacity.

To answer the inevitable question of what prompted a study of black barbers requires a brief historiographical detour. Although a small body of literature on African American business has accumulated over the past thirty years, the topic has labored under the burden of refuting scholars such as Howard University sociologist E. Franklin Frazier,

Enterprise \& Society, Vol. 5 No. 4, () the Business History Conference 2004; all rights reserved.

doi:10.1093/es/khh079

DOUGLAS BRISTOL, JR., is assistant professor of history at the University of Southern Mississippi. Contact information: University of Southern Mississippi, Department of History, 730 East Beach Boulevard, Long Beach, MS 39520, USA. E-mail: douglas.bristol@usm.edu.

I received my Ph.D. from the University of Maryland, College Park, with distinction in December 2002. Ira Berlin served as my advisor; James Gilbert, Alfred Moss, and David Sicilia made up the rest of my dissertation committee. To all of my committee members, I want to express my appreciation, especially to Ira for his searching questions, his generosity with his time, and his example as an engaged scholar. I also am indebted to David Sicilia for encouraging me to think like a business historian. I also gratefully acknowledge the financial support provided by the History Department and the Committee on Africa and the Americas at the University of Maryland, along with a summer postdoctoral fellowship at the Smithsonian National Museum of American History, which I held while writing this article. 
who concluded that "the Negro lacks a business tradition." Frazier and others argued that slavery and discrimination prevented African Americans from acquiring experience in commerce and industry, which explained why there were no black Rosenwalds or Kennedys.

In the broadest terms, such assertions are true insomuch as they disregard small businesses, particularly in the service sector, where African Americans have historically occupied an economic niche. The literature on black property owners documents a range of small business owners who attained a modest prosperity. Among these proprietors, one group stands out for its consistently high level of success-black barbers. On the eve of the Civil War, for example, one out of eight African Americans in the upper South worth at least \$2,000, the standard for affluence at that time, owned a barbershop. A quick review of African American community studies, furthermore, revealed that the prosperity of black barbers held constant over time and space. Individual barbershops routinely flourished for decades after the demise of the founding proprietor, who often left the business to sons, nephews, and grandsons. In addition, black barbers prospered outside the South, achieving as much dominance within the trade in Boston and San Francisco as they did in Baltimore and Charleston. ${ }^{1}$ The phenomenon

1. The scholarship that diminished the accomplishments of black business includes Abram L. Harris, The Negro as Capitalist: A Study of Banking and Business among American Negroes (1936; College Park, Md., 1968); M. S. Stuart, An Economic Detour: A History of Insurance in the Lives of American Negroes (1940; College Park, Md., 1969); E. Franklin Frazier, Black Bourgeoisie (1957; New York, 1990); Nathan Glazer and Daniel Patrick Moynihan, Beyond the Melting Pot: The Negroes, Puerto Ricans, Jews, Italians, and Irish of New York City (Cambridge, Mass., 1964), 30-37; Eugene P. Foley, "The Negro Businessman: In Search of a Tradition,” Daedalus 95 (Winter 1966): 107-44; Ivan Light, Ethnic Enterprise in America: Business and Welfare among Chinese, Japanese, and Blacks (Berkeley, Calif., 1972). For a discussion of how the negative views about black businessmen has dampened interest in the history of black business, see Robert E. Weems, Jr., "Out of the Shadows: Business Enterprise and African American Historiography," Business and Economic History 26 (Fall 1997): 200-12. Quotation from Frazier, Black Bourgeoisie, 165. Notable books that have worked to disprove Frazier include Walter B. Weare, Black Business in the New South: A Social History of the North Carolina Mutual Life Insurance Company (1973; Durham, N.C., 1993); Juliet E. K. Walker, Free Frank: A Black Pioneer on the Antebellum Frontier (Lexington, Ky., 1983); Elsa Barkley Brown, "Womanist Consciousness: Maggie Lena Walker and the Independent Order of St. Luke,” Signs 14 (Spring 1989): 610-33; Alexa Benson Henderson, Atlanta Life Insurance Company: Guardian of Black Economic Dignity (Tuscaloosa, Ala.,1990); Richard A. Plater, African American Entrepreneurship in Richmond, 1890-1940: The Story of R. C. Scott (New York, 1996); Robert E. Weems, Jr., Black Business in the Black Metropolis: The Chicago Metropolitan Insurance Company, 1925-1985 (Bloomington, Ind., 1996); Robert C. Kenzer, Enterprising Southerners: Black Economic Success in North Carolina, 1865-1915 (Charlottesville, Va., 1997); Juliet E. K. Walker, The History of Black Business in America: Capitalism, Race, Entrepreneurship (New York, 1998); Loren Schweninger, Black Property Owners in the South, 1750-1915 (Urbana, Ill., 1990), 121. 
of black barbers, although often noted in passing, has not been studied in depth. This dissertation began as an attempt to understand how black barbers developed into the paragons of African American enterprise and why, generation after generation, they remained successful.

Black barbers amassed substantial wealth in the nineteenth century through a feat unparalleled in the history of African American business: they competed against white barbers for white customers, and they won. From the 1820s to the Great Migration almost a century later, they dominated the upscale market serving affluent white men even as other African American business people lost their white clientele. The accomplishment of black barbers is especially remarkable in light of the fact that shaving, rather than haircutting, was the mainstay of nineteenth-century barbers. Consequently, this is the story of the black man's razor at the white man's throat. Understanding the appeal of black barbers to white customers required turning to literature and travelers' accounts.

In a scene from Herman Melville's novella Benito Cereno that describes a slave shaving his master, the protagonist, Captain Delano, articulates commonly held white stereotypes about black barbers. "There is something in the Negro," avows Delano, "which, in a particular way, fits him for avocations about one's person. Most Negroes are natural valets and hairdressers." Describing how black men performed such work, Delano expresses admiration for their refinement. "There is," he says, "a smooth tact about them in this employment, with a marvelous, noiseless, gliding briskness, not ungraceful in its way, singularly pleasing to behold, and still more so to be the manipulated subject of." Delano ascribes these gifts to an innate dependency, "that susceptibility of blind attachment sometimes inhering in indisputable inferiors." ${ }^{2}$ In this description, the black barber emerges as a liminal figure, at once genteel and servile, with the ability to confer distinction while also validating the racial superiority of a white man. Black barbers self-consciously developed this persona in order to transform the mundane act of shaving into a luxurious ritual for which there was high demand.

A perceptive understanding of their customers, in the sense of W. E. B. DuBois's concept of double-consciousness, allowed black

2. Herman Melville, Billy Budd and Other Tales (1856; New York, 1979), 73. The fact that most antebellum whites failed to perceive the true character of African Americans is the fulcrum of Melville's story. In actuality, Delano is taken in by the act of Babo, who poses as a devoted slave although he is the leader of a slave mutiny. For a discussion of this point, see Sterling Brown, The Negro in American Fiction (New York, 1969), 12. For an overview of white Americans searching for distinction as genteel people, see Richard L. Bushman, The Refinement of America: Persons, Houses, Cities (New York, 1993). 
barbers to capitalize on racial stereotypes. Because they understood how whites saw them, they were able to create masks that white customers found appealing. Pierre Toussaint, a former Haitian slave who became the Vidal Sasson of New York City in the early Republic, so perfectly embodied the qualities that whites admired in African Americans that one of his obituaries read, "Uncle Tom Not An Apocryphal Character." The death notice in the New York Post went on to suggest that Toussaint could have served as the model for the lead character in Harriet Beecher Stowe's novel.

In the personal papers they left behind, black barbers acknowledged the limits of white respect, as well as a determination to think for themselves. A letter from an old friend of Toussaint's addressed this issue directly. "You may," he wrote, "indeed change your condition, but you cannot change your complexion." The problem, he continued, sprang from how many white Americans "think that a black skin prevents us from seeing and understanding good from evil," in other words, from being capable of discernment and good judgment. "Courage!" he urged Toussaint, "let them think as they please." As for his friend, the correspondent expressed faith in Toussaint's pragmatism because he knew that the black barber had not deluded himself into believing that "they mistake you for a white man." Toussaint's success, he concluded, derived from confronting the "naked truth" about race relations. ${ }^{3}$ The willingness of black barbers to accept and exploit the racial stereotypes of their white customers represented an entrepreneurial innovation that secured their economic niche.

Growing competition after 1850 meant that black barbers had to continue this process of innovation by transforming their shops. Household-level data on occupations in the United States manuscript census reveals that black barbers had been eclipsed by white immigrants during the 1850s, when African Americans slipped from being the majority of barbers to the minority. Yet the census also

3. DuBois defined double-consciousness as the sense "of always looking at one's self through the eyes of others, of measuring one's soul by the tape of a world that looks on in amused contempt and pity." Nathan Irving Huggins observes that there was a corollary to double-consciousness, "a unique insight into the vulnerable and unfulfilled soul" of white people. In her study of black female domestics, Darlene Clark Hine identifies a similar strategy, a "culture of dissemblance" that "created the appearance of openness and disclosure" to their employers while shielding themselves from debilitating racial and gendered stereotypes. W. E. B. DuBois, The Souls of Black Folk, ed. Henry Louis Gates, Jr., and Terri Hume Oliver (1903; New York, 1999), 11; Nathan Irving Huggins, Harlem Renaissance (New York, 1971), 244-45; Darlene Clark Hine, "Rape and the Inner Lives of Black Women in the Middle West: Preliminary Thoughts on the Culture of Dissemblance," Signs 14 (Summer 1989): 342-47. New York Post obituary and correspondence reprinted in Hannah Farnham Lee, Memoir of Pierre Toussaint: Born a Slave in St. Domingo (1854; Westport, Conn., 1970), 96-98, 119-22. 
shows that black barbers, on average, still had equal or greater wealth than white barbers. From the records of black-owned barbershops and the pages of the city directory, it becomes apparent that black barbers maintained an edge over their white competitors through better locations and nicer establishments. African American barbershop owners guaranteed their access to affluent white customers by purchasing or leasing buildings in downtown commercial districts, establishing black outposts in an otherwise exclusively white retail landscape. In Philadelphia, black barbers conducted business in the heart of the city's fashionable shopping district surrounding Chestnut Street. James Auter, whose barbershop was located at 317 Chestnut Street, a few doors down from the Chestnut Street House Hotel, had a continuous supply of desirable customers close at hand. Moreover, the upscale character of the surrounding businesses also brought affluent customers his way. On Auter's block alone, retailers sold jewelry, silver, wallpaper, and books to the public. Joshua Eddy, who would become the wealthiest black barber in America, reputedly worth $\$ 100,000$, owned a shop one block farther westward on Chestnut, and he also had prestigious neighbors, including a jeweler, a portrait painter, and a French wig maker. ${ }^{4}$ Although securing advantageous locations for their shops reflected good business judgment, black barbers displayed genuine entrepreneurial skill by introducing a new concept-the first-class barbershop.

To make their shops more appealing to white customers, black barbers installed public parlors that emulated the salons of aristocratic mansions and made experiencing luxury part of the service they provided to customers. Black barbers frequently notified the public of their improvements by advertising their "shaving saloon," which was a popularization of the term salon, to indicate that they operated, in the parlance of the day, a first-class business. For example, William Roberson's advertisements in the St. Louis city directory for his Marble Palace, a "Bathing and Shaving Saloon," illustrated the lengths some black barbers went to ensure that their customers enjoyed the height of fashion. Sitting in upholstered reclining chairs

4. I examined household-level entries for occupation, real property, and personal property in the manuscript census returns for Philadelphia, Baltimore, and Mobile to compare the North, the upper South, and the lower South. Seventh Census of the United States, 1850. Population, Slave, and Manufacturing Schedules \& Eighth Census of the United States, 1860. Population, Slave, and Manufacturing Schedules, Records of the Bureau of the Census, Record Group 29, National Archives, Washington, D.C. In one directory, businesses were listed by their addresses, which made it possible to determine what establishments conducted business on a given block: The Philadelphia Shopping Guide and Housekeeper's Companion (Philadelphia, Pa.,1859). 
under ceilings with elaborate plaster fretwork, the customers of Roberson's establishment watched the progress of their shave in large, gilt-framed mirrors lit by an enormous chandelier. They might choose to walk across the vast brocade carpet in Roberson's capacious shampooing room to seek additional pampering from another attendant. Afterward, they had their choice of a sulfur, steam, mercurial, iodine, perfumed, salt, hot, cold, or showered bath. Roberson also discretely set aside private rooms for removing corns and bunions. In addition to upgrading the trappings of their shops, black barbers started retailing an array of hair-care products, men's clothing accessories, and, in at least some barbershops, thousands of cigars and gallons of cologne. Growing affluence and the rise of mass consumption in the latter half of the nineteenth century raised the bar for attracting prosperous white customers, and in a new marketplace where retailers such as John Wannamaker set the standards, black barbershop proprietors who wished to remain competitive had to increase the size of their capital investment and staff. ${ }^{5}$

The most successful black barbers elevated the first-class barbershop to its highest form in the latter half of the nineteenth century, and the investments they made in ever more luxurious shops made these establishments the pinnacle of black business achievement in the late nineteenth century. According to an 1899 study of blackowned businesses, more barbers had invested $\$ 500$ or more in their business than any other group of African American business people, except for grocers and general store owners, and barbers nearly tied them for second place. Unlike the grocers and general store owners, whose capital was tied up in inventory, barbers invested mainly in capital improvements in prominent commercial buildings. The study also found that twice as many barbers had invested \$500 in their shops as had proprietors in the next three highest ranking types of businesses: publishers, undertakers, and saloon keepers. Furthermore, more than half of the barbers in the study had a $\$ 1,000$ or more invested in their shops. Barbers, in short, towered over the majority of their fellow black businessmen in terms of capital.

5. Katherine Grier examines the development of such commercialized parlors in Culture and Comfort: People, Parlors, and Upholstery, 1850-1930 (Amherst, Mass., 1988), 22-59, 61-63. The ad for Roberson's barbershop is contained in the Rapier Family Papers, Series D-Cards, Box 84-2, File 108, Moorland-Spingarn Research Center, Howard University, Washington, D.C. Massive purchases of cigars and cologne are recorded in Jacob White's business records, John C. White, Sr.; B \& R; 1839-1841; American Negro Historical Society Collection; Reel 5; frames 12, 103, 117, 153; Historical Society of Pennsylvania, Philadelphia. For an overview of the dramatic changes in retailing at the end of the nineteenth century, see William Leach, Land of Desire: Merchants, Power, and the Rise of a New American Culture (New York, 1993). 
In Cleveland, three barbers each had more capital invested than any other black-owned business in the city, and the $\$ 21,000$ capitalization of their three barbershops together surpassed the total amount of money invested in all other African American businesses in Cleveland. Staffs ranging from twelve to thirty employees also distinguished the Cleveland barbershops from other African American businesses, which typically employed no more than two or three people. ${ }^{6}$ Although the expansion of black-owned barbershops and the corresponding growth in the number of staff ultimately generated tensions between proprietors and their employees, solidarity among black barbers had been the prerequisite for introducing first-class shops and staving off white competition.

Black barbers maintained harmony within their ranks by preserving the artisan system. Designed to provide stable employment, decent prices, and a common identity, this system was based on a series of reciprocal relationships. Black barbers started their careers as apprentices living under the roof and supervision of barbershop proprietors who instructed them in the tonsorial arts, the three Rs, and morals. In exchange, the elder barbers not only secured inexpensive help in their shops, but they also maintained high levels of skill within the trade and limited competition. Barbershop owners looked out for journeymen barbers as well. In addition to socializing with their employees and allowing them to court their daughters, the boss barber, as he was often called, sought to help his barbers open their own shops. These bonds of mutuality grew out of informal and formal social networks rooted in the African American community. Relatives, neighbors, and fellow church members looked to barbers they knew to take on their sons as apprentices, enmeshing the barbershop into tightly knit urban black society. Similarly, while barbers organized mutual aid societies to provide themselves with sickness and death benefits, they also used these organizations to affirm community ties through events such as the Barbers' Beneficial Association's annual picnic in Baltimore, which drew more than one thousand African Americans in 1859. The strong tradition of mutual aid in the African American community explains why black barbers

6. W. E. B. DuBois, ed. The Negro in Business; Report of a Social Study Made under the Direction of Atlanta University Together with the Proceedings of the Fourth Conference for the Study of Negro Problems, Held at Atlanta University, May 30-31, 1899 (Atlanta., Ga., 1899), 6-9, 16, 37-38. John A. Garraty, ed., The Barber and the Historian: The Correspondence of George A. Myers and James Ford Rhodes, 1910-1923 (Columbus, Ohio, 1956), xvi-xvii; Kenneth L. Kusmer, A Ghetto Takes Shape: Black Cleveland, 1870-1930 (Urbana, Ill., 1976), 76; David A. Gerber, Black Ohio and the Color Line, 1860-1915 (Urbana, Ill., 1976), 308. 
could retain the artisan system at a time when it declined among white barbers, who, as a result, faced cutthroat competition. ${ }^{7}$

By working together to create a distinct form of service based on catering to the racial stereotypes of white customers in a luxurious setting, black barbers created a tradition of enterprise that allowed them to fend off white competitors and dominate the upscale portion of the trade for a dozen generations. This accomplishment needs to be viewed in the context of extremely limited opportunities for African Americans to become proprietors or even to work for a black employer. Accordingly, the wealth of black barbershop owners, their entrepreneurial innovations, the amount of capital that they invested, and the number of people they employed cannot be compared to the leading white industrialists or retailers. Yet investigating these issues reveals that black barbers occupied the leading ranks of African American entrepreneurs and underscores the value of employing the perspective of business history to research African American topics. When these findings are viewed from the perspective of social history, however, new questions emerge concerning the aspirations that black barbers sought to fulfill through their businesses and their vantage point on race relations. Understanding the paradox of black barbers operating segregated businesses while they served as leaders within the African American community provides a way to explore these issues of agency and identity.

Black barbers received criticism for maintaining the color line in their shops, and, in their defense, they pleaded economic necessity, disclosing a pragmatic outlook on racial uplift. Adopting a position held by many black leaders during the nineteenth century, the delegates of the 1852 Ohio Colored Convention passed a resolution condemning black barbers. Because they refused to serve African Americans, reasoned the delegates, black barbers were "much worse than a white man who refuses to eat, drink, ride, walk, or be educated with a colored man because [they are] colored." The incendiary black abolitionist David Walker added to these complaints by objecting to the servile nature of the work of barbers, contending that the man who had no higher aspirations than "wielding the razor" was "ignorant and wretched." In his mind, the deference of barbers to their

7. The decline of the artisan system is traced in W. J. Rorabaugh, The Craft Apprentice: From Franklin to the Machine Age in America (New York, 1986). Weekly Anglo-African, 20 Aug. 1859, p. 3.

8. Philip S. Foner and George E. Walker, eds., Proceedings of the Black State Conventions, 1840-1865, vol. 1 (Philadelphia, Pa., 1979), 277; David Walker, Appeal to the Coloured Citizens of the World, ed. Peter P. Hinks (University Park, Pa., 2000), 29. For an overview of this debate, see Patrick Rael, Black Identity and Black Protest in the Antebellum North (Chapel Hill, N.C., 2002). 
customers differed little from the submissiveness of slaves to their masters. Running through these criticisms was a question of how to balance the need for self-esteem against the need for a livelihood in an economy that marginalized African Americans. During the 1850s, a debate over whether African Americans should avoid employment deemed servile in the black press and at leadership conventions crystallized these issues, as well as how barbers felt about criticism of their profession.

Black barbers responded to criticism from the African American community by stressing their importance as businessmen and the contribution that business made to the African American community. Barbers were, wrote one in a letter to the editor of a black newspaper, "as intelligent and respectable as any other class of business men, and much more so than others." Pointing out that barbers also represented "a very large class of business men among our people," he implied that criticism of barbers was tantamount to an attack on black enterprise. Fortunately, barbers had a distinguished spokesman on their behalf in the person of Lewis Woodson. The most prominent leader to emerge from the ranks of barbers, Woodson criticized the factious spirit in leadership circles that prevented unity from developing. He also expressed impatience with the concerns of some leaders about respectability and cultural attainments, noting tartly that "our efforts to obtain wealth have not been equal to our efforts to obtain knowledge." According to Woodson, business should be the chief concern of African Americans because it provided "an easy, practical, and certain means" of bettering the condition of the race. ${ }^{9}$ Although, on some level, these disagreements about the means and ends of racial uplift exposed a competition for status within the African American community, the Virginia-born Woodson's remarks also articulated the viewpoint of barbers from the upper South.

Lewis Woodson's emphasis on business success reflected the options available to free blacks in the upper South during the antebellum period. Since laws in the region prohibited or restricted the ability of free blacks to establish their own organizations, such as churches or mutual aid societies, community leadership did not offer an outlet for their ambitions in the same way that it did for northern black people. Free blacks in the upper South turned to the marketplace for a sense of accomplishment instead. When the barber Cyprian Clamorgan wrote a profile of the black elite in St. Louis, he

9. Frederick Douglass' Paper, 22 April 1853, 23 Dec. 1853, and 28 Dec. 1853; Pennsylvania Freeman, 27 June 1850. For background on Woodson, see Floyd J. Miller, "The Father of Black Nationalism: Another Contender," Civil War History 17 (Dec. 1971): 310-19. 
began each biographical sketch with an estimate of the individual's net worth. He also quoted a motto of one of his subjects approvingly: "Wealth makes the man, the want of it the fellow."

Given this outlook, it is not surprising that the leading black barbers came disproportionately from the upper South even when they settled in other parts of the country. Black barbers from the upper South who migrated to Philadelphia stood out from their peers. Out of the sixteen black barbers in the city who owned real estate, seven came from the upper South. Not all barbers from the upper South moved up the Atlantic Coast. After working as a personal servant in Virginia, George Baptiste moved to Madison, Indiana, in 1838 before moving again to Detroit, where he became one of the city's wealthiest barbers. John Rapier originally came from Nashville but gained his freedom in Florence, Alabama, where he operated a barbershop that helped him become the twelfth wealthiest black person in the state. Because they had a worldview that equated prosperity with success, black barbers from the upper South could flourish anywhere in the United States. The Fourteenth Amendment ended constraints on the rights of African Americans to organize in the upper South, but black barbers from the region remained focused on economic accomplishments. In his only known public address, John Merrick, the leading barber of Durham, North Carolina, discussed the bloody Wilmington Riot of 1898 in terms of his conviction that the African American community should have forsaken politics for business after Reconstruction. "Had the Negroes of Wilmington owned half of the city and county," he argued, "there wouldn't [sic] anything happened to compare with what they did." ${ }^{10}$ Echoing the sentiments of his friend Booker T. Washington, Merrick displayed the legacy of his regional heritage by voicing the ongoing commitment among black barbers to economic self-help.

The deterioration of race relations at the end of the nineteenth century tested the faith of black barbers in the marketplace. Since black barbers had designed their businesses to accommodate white prejudice, they were equipped to deal with a hostile racial climate.

10. For an overview of regional differences among free blacks, see Ira Berlin, "The Structure of the Free Negro Caste in the Antebellum United States," Journal of Social History 9 (Spring 1976): 297-318; Julie Winch, ed., The Colored Aristocracy of St. Louis by Cyprian Clamorgan (Columbia, Mo., 1999), 49; Various entries, Philadelphia, Pennsylvania, U.S. Census, 1860, reel 1157, pp. 71, 72, 84, 87, 94, 122, 149, 207, 268, 523, 537, 711, 715, 757; David M. Katzman, Before the Ghetto: Black Detroit in the Nineteenth Century (Urbana, Ill., 1973), 14; Emma Lou Thornbrough, The Negro in Indiana before 1900 (Bloomington, Ind., 1993), 42; Loren Schweninger, James T. Rapier and Reconstruction (Chicago, 1978), 1-4. Merrick quotation in Robert McCants Andrews, John Merrick: A Biographical Sketch (Durham, N.C., 1920), 159. 
Moreover the passage of segregation laws merely sanctioned timehonored custom, for black barbers had long refused service to African Americans. Yet nothing could prepare them for attacks by white mobs. As the antipathy that white southerners had customarily felt toward African Americans grew into rage during the 1890s, southern black barbers paused to consider the ramifications of serving white men in such a harsh racial climate and turned to the market presented by growing black urban enclaves. An attack on his Peachtree Street barbershop by a white mob during the 1906 Atlanta Riot prompted the city's leading black barber, Alonzo Herndon, to send his son to Philadelphia for school and consider abandoning the South. Instead, he turned his attention to operating a small insurance firm that served African Americans, and under his direction the Atlanta Life Insurance Company grew to be one of the foremost black-owned corporations in the nation. Herndon also repaired the damage to his Peachtree barbershop and resumed serving white customers, exhibiting a cautious strategy of diversification followed by other black barbers. After a 1904 riot by a white mob in Mobile, black barbers accelerated a shift from serving white customers downtown to serving black customers in the segregated Davis Avenue neighborhood. Nevertheless, black barbers continued to maintain outposts in the central business district. The city's preeminent black barbers, Edgar Harney and Andrew Jackson, decided to remain downtown after a fire destroyed their previous location the same year as the Mobile race riot, but they also branched out, serving African Americans in a barbershop and a funeral parlor. ${ }^{11}$ By not rushing to abandon their outposts in white commercial districts, black barbers demonstrated that they judged the hazards of close proximity to whites to be acceptable, suggesting that race relations had not changed as dramatically as the wave of violence rolling through the South would seem to indicate. Black barbers also proved that, when urban black enclaves had grown enough to represent a lucrative market, they could reinvent their tradition of enterprise to serve African Americans.

In the North, however, the long-term effects of changing race relations became apparent in a fight over whether states should license

11. Alexa Benson Henderson, Atlanta Life Insurance Company: Guardian of Black Economic Dignity (Tuscaloosa, Ala., 1990), 17, 24, 29; Paulette DavisHorton, Davis Avenue: The Place, the People, the Memories (Mobile, Ala., 1991), 115, 166; James P. Hall (grandson of Edgar Harney), interview with author, Mobile, Ala., 13 and 14 Aug. 1997. I identified all barbers in Mobile through the manuscript census returns. Barbershop ownership and shop location were determined by looking the men up in Mobile City Directories and referring to Sanborn Fire Insurance maps. 
barbers. White barbers in the Journeyman Barbers' International Union of America (JBIUA) began a campaign in 1896 to secure the passage of state licensing laws that allowed union members to exclude African Americans from the trade. By raising concerns about the spread of disease within barbershops, the union proposals, even when defeated by black barbers, succeeded at convincing white Americans that hygiene, instead of the genteel deference for which black barbers were known, represented the most important qualifications of a barber. White physicians at the time routinely branded African Americans as disease carriers, so the JBIUA public health campaign surely triggered associations between blackness and illness. Consequently, barbershop proprietors could inoculate their customers against succumbing to their prejudices by displaying the latest in sterilization equipment, but most could not afford the investment. ${ }^{12}$ Black barbers had a long record of exploiting the black image in the white mind to keep their lucrative outposts, but they had few ways to influence the shifting American discourse about race.

Exploring how black barbers justified segregating their businesses and why they switched to black customers provides new insights into the ways that African Americans struggled with racial ideology and racism. Convinced that wealth provided the best means for overcoming the disabilities of race, black barbers pragmatically catered to affluent white men, while urging members of their community to swallow their pride and chase after dollars. This belief reflected the influence of barbers from the upper South, where circumstances dictated by antebellum race relations had oriented African Americans toward the marketplace, a predilection they retained after the Civil War. With the advent of Jim Crow, black barbers again exhibited a matter-of-fact attitude toward their situation as African American businessmen, gradually withdrawing from their outposts in white commercial districts as opportunities presented themselves in segregated black enclaves. At the same time, conceding the market they had dominated so long to white barbers also revealed limits on the ability of black barbers to shape white racial stereotypes. They could get white men to line up for their chair by playing Uncle Tom, but, as their erstwhile customers came to see them as violent and

12. I discuss the licensing movement in Douglas Bristol, Jr., "The Victory of Black Barbers over Reform in Ohio, 1902-1913," Essays in Economic and Business History 16 (1998): 251-60. For a case study that examines the association of African Americans with tuberculosis, see Tera W. Hunter, To 'Joy My Freedom: Southern Black Women's Lives and Labors after the Civil War (Cambridge, Mass., 1997), chap. 9. Another book that examines how racial ideas defined issues of black health is Keith Wailoo, Dying in the City of the Blues: Sickle Cell Anemia and the Politics of Race and Health (Chapel Hill, N.C., 2001). 
disease-ridden, they gradually lost the audience for their performance. Although black barbers privately expressed contempt for whites and dissatisfaction with the role they had to play, they still managed to turn an economic niche into a vehicle for their own empowerment.

The story of black barbers illustrates the value of exploring connections between the fields of business and African American history. By documenting how these African American men used entrepreneurial skills, trade customs, and community ties to create a tradition of enterprise, this dissertation pushes those studying black business people to go beyond the study of exceptional individuals. It also underscores the need for historians of African Americans to explore the influence of business people and regional differences in debates over how best to uplift the race. Additionally, black barbers stand witness to the fact that African Americans were not the passive objects of racial ideology and had the ability to capitalize on white prejudice for their own benefit. The experience of these remarkable entrepreneurs also points to the need for further research in business history. By documenting the integral role that performance and relationship-building played in the success of black barbers, this dissertation highlights the need to examine interpersonal skills in economic activity such as sales. ${ }^{13}$ Finally, barbering is merely one of a plethora of largely ignored service businesses that have always made up the bulk of firms in the United States and that now employ most Americans. Small service firms in particular, with their minimal costs for startup, have significance beyond their size and profits, for they are the most tangible connection between Americans and the dream of business ownership. 